\title{
Community-based HCV screening: knowledge and attitudes in a high risk urban population
}

\author{
Brianna L Norton ${ }^{*}$, Corrine I Voils ${ }^{2}$, Sarah H Timberlake ${ }^{3}$, Emily J Hecker ${ }^{1}$, Neela D Goswami ${ }^{1}$, Kim M Huffman ${ }^{4}$, \\ Anneka Landgraf ${ }^{3}$, Susanna Naggie ${ }^{1}$ and Jason E Stout ${ }^{1}$
}

\begin{abstract}
Background: In an attempt to curtail the rising morbidity and mortality from undiagnosed HCV (hepatitis C virus) in the United States, screening guidelines have been expanded to high-risk individuals and persons born 1945-1965. Community-based screening may be one strategy in which to reach such persons; however, the acceptance of HCV testing, when many high-risk individuals may not have access to HCV specific medications, remains unknown.

Methods: We set out to assess attitudes about HCV screening and knowledge about HCV disease at several community-based testing sites that serve high-risk populations. This assessment was paired with a brief HCV educational intervention, followed by post-education evaluation.

Results: Participants $(n=140)$ were surveyed at five sites; two homeless shelters, two drug rehabilitation centers, and a women's "drop-in" center. Personal acceptance of HCV testing was almost unanimous, and $90 \%$ of participants reported that they would still want to be tested even if they were unable to receive HCV treatment. Baseline hepatitis $\mathrm{C}$ knowledge was poor; however, the brief educational intervention significantly improved knowledge and increased acceptability of testing when medical access issues were explicitly stated.

Conclusions: Despite inconsistencies in access to care and treatment, high-risk communities want to know their HCV status. Though baseline HCV knowledge was poor in this population, a brief on-site educational intervention improved both knowledge and acceptability of HCV testing and care. These data support the establishment of programs that utilize community-based screening, and also provide initial evidence for acceptance of the implementation of the recently expanded screening guidelines among marginalized communities.
\end{abstract}

Keywords: Health knowledge, Attitudes, Behaviors, Healthcare disparities, Hepatitis C, Patient education, Screening

\section{Background}

Hepatitis $\mathrm{C}$ virus (HCV) is the most common bloodborne infection in the United States (US), with an estimated 4 million persons chronically infected [1]. It is the leading cause of end-stage liver disease and hepatocellular carcinoma, as well as the most common indication for liver transplantation [2,3]. Due to lack of provider, patient, and community awareness, as well as conflicting screening guidelines, this epidemic has gone largely unnoticed [2]. Consequently, $75 \%$ of persons living with $\mathrm{HCV}$ are unaware of their infection $[4,5]$ and thus are at risk of developing serious sequelae of liver disease,

\footnotetext{
*Correspondence: bnorton@montefiore.org

'Division of Infectious Diseases and International Health, Duke University Medical Center, Box 102358, Durham, NC 27710, USA

Full list of author information is available at the end of the article
}

without an opportunity for treatment and appropriate disease management. In 2007, the number of persons dying from HCV exceeded that of HIV [6], and without imminent intervention, multiple models predict a fourfold increase in morbidity and mortality from $\mathrm{HCV}$ over the next decade $[7,8]$.

In an attempt to curb this epidemic and identify more people living with $\mathrm{HCV}$, national screening guidelines from the Centers for Disease Control (CDC), and now the United States Preventative Task Force (USPSTF), have recently expanded to include asymptomatic individuals who belong to high-risk groups (persons injecting/ever-injected drugs, recipients of blood products or organ transplants prior to 1992, hemodialysis patients, and persons with persistently abnormal liver enzymes), as well as one-time testing in all baby-boomers (persons

\section{Biomed Central}

(c) 2014 Norton et al.; licensee BioMed Central Ltd. This is an open access article distributed under the terms of the Creative Commons Attribution License (http://creativecommons.org/licenses/by/2.0), which permits unrestricted use, distribution, and reproduction in any medium, provided the original work is properly cited. 
born between 1945-1965) [9-11]. Though these guidelines may encourage further testing within health care settings, one limitation of these screening strategies is that many persons with $\mathrm{HCV}$ do not have access to healthcare. Community-based screening strategies, via health departments, methadone maintenance programs, or homeless shelters may be one approach in which to reach such persons. The Department of Health and Human Services (DHHS) Viral Hepatitis Action Plan specifically calls for outreach to high-risk communities to provide opportunities to get tested, seek care, and engage in HCV education strategies [2]. The acceptance of such interventions, particularly when many high-risk individuals may not have access to HCV medications, remains unknown. We set out to assess attitudes surrounding HCV screening, as well as knowledge regarding $\mathrm{HCV}$ disease and treatment at several community-based testing sites that serve high-risk populations. This assessment was paired with a brief $\mathrm{HCV}$ educational intervention, with the aim of also evaluating post-education changes in knowledge and attitudes.

\section{Methods}

\section{Setting and participants}

Sites were chosen from a list of community-based HIV/ sexually transmitted diseases testing sites utilized by the local public health department (Wake County Human Services). These sites- a homeless shelter, drug rehabilitation center, and drop-in center- were chosen because they serve poor, marginalized communities, of whom many are/were persons who injected drugs (PWID), thereby putting them at-risk for HCV. The S. Wilmington Street shelter is the largest homeless shelter in Raleigh, North Carolina with 234 beds, serving only men. The Raleigh Rescue Mission, another homeless shelter, serves both men and women and has 100 beds. The Healing Place (for men and women) is a recovery and rehabilitation facility for homeless people with alcohol and drug dependency. There are 180 beds at the men's facility and 95 at the women's facility. The Women's Center of Wake County is a multi-service resource center that addresses issues of poverty, homelessness, and substance abuse for single women and women with families. A convenience sample of persons attending each of these settings was surveyed. The leaders of each community center advertised the study for one week prior to the event, and members chose whether to attend the program. All interviews and education took place at each site during regular hours of operation. Participation was voluntary; interest was overwhelming. The study period took place from January 2012 to May 2012. The inclusion criteria were: 1) speak/understand English; 2) age 18 or older; (3) willingness to complete a pre and post-test survey instrument and participate in a short educational intervention. The survey was anonymous and clearly labeled as to its purpose (research study), and verbal consent was performed. No identifying information was obtained from subjects, and they were compensated for participation with a five dollar grocery store gift card. The study was exempted from institutional review board review by the Duke University Medical Center Institutional Review Board.

\section{Study intervention}

An educational intervention was given as well as pre- and post-intervention surveys. Pre- and post-intervention survey instruments were administered verbally to participants to assess knowledge and attitudes surrounding hepatitis $\mathrm{C}$ disease, testing, and treatment.

The survey instrument assessed socio-demographic information, access to healthcare, knowledge of $\mathrm{HCV}$, and attitudes toward community HCV screening. The survey was first piloted among patients in the Duke Infectious Diseases clinic to assess question comprehension, and revisions were made accordingly. To ensure full comprehension, study investigators verbally administered the survey instruments to all participants. The post-intervention survey was performed directly after the educational intervention and consisted of a subset of the pre-intervention questions.

The educational intervention consisted of a brief (approximately 15 minute) standardized discussion of the epidemiology of $\mathrm{HCV}$, clinical significance, care and treatment options, and preventative strategies, followed by a question/answer session. A spiral-bound flip-book with diagrams was used with the discussion. The intervention was designed with the assistance of professional health educators and was directed toward a fifth grade education level. The same investigator (B.N.) delivered the educational program at each site in order to maximize the consistency of the educational intervention across sites.

\section{Statistical analysis}

The study was powered on the primary objective: assessment of screening acceptability. We chose a sample size that would permit adequate assessment of whether a majority (i.e., $>50 \%$ ) of participants felt that HCV screening would be acceptable in their community. Assuming that the true rate of $\mathrm{HCV}$ testing acceptance in the community was $60 \%$ in the underlying population, we needed 153 participants to exclude an acceptability rate of $<50 \%$ with $80 \%$ power at a $5 \%$ type 1 error rate, using a one-sided significance test. The study was stopped early due to overwhelming acceptance of screening.

Continuous variables were summarized using medians/ quartiles or means/standard deviations, as appropriate to the distribution. Categorical variables were summarized with frequency counts/proportions. Changes in knowledge and acceptance of $\mathrm{HCV}$ testing were assessed using the 
McNemar test to compare baseline and post-education responses. Answers of "not sure" were considered not correct (knowledge) or negative for acceptance. We created a composite knowledge score from 18 knowledge-related questions, assigning each correct answer one point. Bivariate associations between baseline knowledge and pre-selected predictor variables were assessed using t-tests with categorical variables or Pearson correlations with continuous variables. All variables significantly associated with knowledge at an alpha of $<0.05$ were then entered into a multivariable linear regression model, centering the age variable in the model.

\section{Results}

\section{Demographics}

One hundred forty participants were surveyed at 5 sites, including 2 homeless shelters, 2 drug rehabilitation centers, and a women's "drop-in" center. The majority of participants were male (66\%) and African American (57\%) (Table 1). The median age was 43 years old, with a range of 18 to 62 years. Participants varied in education levels, with $16 \%$ having stopped education after elementary school. Most people had no health insurance (73\%), and less than half stated they had a regular doctor (49\%).

Table 1 Patient demographics

\begin{tabular}{ll}
\hline Patient characteristics & \% ( $\mathbf{n = 1 4 0 )}$ \\
\hline Intervention site & \\
Healing Place for Men (Drug Rehabilitation Center) & $35 \%$ \\
Healing Place for Women (Drug Rehabilitation Center) & $16 \%$ \\
Wilmington St. Homeless Shelter & $21 \%$ \\
Women's Center (Drop-in Center) & $13 \%$ \\
Raleigh Rescue Mission (Homeless Shelter) & $15 \%$ \\
Male & $66 \%$ \\
Age (median, IQR) & $46(33,54)$ \\
Race & \\
$\quad$ White & $37 \%$ \\
Black & $57 \%$ \\
Other & $6 \%$ \\
Education & \\
Elementary & \\
High school & $16 \%$ \\
Some college & $39 \%$ \\
Finished college & $31 \%$ \\
Insurance & $14 \%$ \\
None & \\
Medicaid/medicare & \\
Private & $73 \%$ \\
Has regular doctor & $12 \%$ \\
\hline
\end{tabular}

Ninety-five percent of participants had heard of $\mathrm{HCV}$, $56 \%$ said they knew someone with the disease, and $18 \%$ of participants stated that they had been diagnosed with $\mathrm{HCV}$. Though all of these participants were surveyed at community centers serving high-risk individuals, 36\% of participants still believed they were "not at all" likely to get $\mathrm{HCV}$.

\section{Baseline attitudes}

Baseline attitudes and knowledge regarding $\mathrm{HCV}$ and HCV screening are presented in Table 2. Baseline acceptance of community-based screening was almost universal. Ninety-seven percent of participants stated they would get a free $\mathrm{HCV}$ test if it were offered, with $90 \%$ reporting that they would still want to be tested even if they were not able to receive treatment. When told that, if positive, they would be offered free vaccines against hepatitis A and B, or lifestyle advice on how to stay healthy with HCV, additional people wanted to be tested even if treatment was not accessible to them (95\% and 96\% respectively).

Almost all participants (99\%) said that they wanted free $\mathrm{HCV}$ testing in their community, but participants were less positive when asked if other people in their community would want free HCV testing in the community (86\%). Almost half (49\%) thought that offering community-based screening without the availability of universal treatment would be problematic. Also, only $39 \%$ of participants believed that others in their community who tested positive for HCV would drink less alcohol. But most believed that HCV positive persons would get vaccinated against hepatitis A and hepatitis B (83\%) or go to the doctor for treatment (76\%).

\section{Baseline knowledge}

Baseline knowledge about HCV acquisition was variable. Although $90 \%$ of people knew that injecting drugs and getting a homemade tattoo are risk factors for HCV, $22 \%$ of people did not think sexual acquisition was possible, $17 \%$ thought $\mathrm{HCV}$ was transmitted from public toilets, and $28 \%$ thought HCV was transmitted from coughing or sneezing. Many people did not know what risk factors were associated with disease progression. Participants' baseline knowledge concerning $\mathrm{HCV}$ treatment was also low. Sixty five percent of participants did not think HCV could be cured or did not know if it could be cured, yet $76 \%$ believed that everyone diagnosed with HCV needed to be treated. Ninety-eight percent of participants said they would want treatment if they tested positive for $\mathrm{HCV}$; however, 63\% did not know about treatment side effects or thought that side effects of therapy were minimal.

\section{Changes in knowledge and attitudes post-intervention} The brief educational intervention significantly improved knowledge about HCV (Table 3). Eighty-one (81\%) 
Table 2 Proportions and frequencies of pre-test survey answers

Questions $(\mathbf{n}=\mathbf{1 4 0})$
Have you heard of HCV?
Do you know anyone who has HCV?
Have you been told you have HCV?
How likely do you think you are to get HCV?* (n
Not at all
Somewhat
Very
Not sure
How do you think people get HCV infection?**
Having sex?
Shooting up (injecting) drugs?
Using public toilets?
Sharing supplies for snorting drugs?
Coughing/sneezing on someone?
Getting a homemade tattoo?

Yes No Unsure

95\% $\quad 4 \% \quad 0.7 \%$

$\begin{array}{llll}56 \% & 39 \% & 4 \%\end{array}$

$18 \% \quad 80 \% \quad 2 \%$

$36 \%$

$29 \%$

$10 \%$

$26 \%$

$56 \% \quad 22 \% \quad 22 \%$

$90 \% \quad 1 \% \quad 9 \%$

$17 \% \quad 60 \% \quad 23 \%$

$54 \% \quad 26 \% \quad 20 \%$

$28 \% \quad 51 \% \quad 21 \%$

$90 \% \quad 2 \% \quad 9 \%$

Which of the following problems can HCV cause to your body?*

Stroke?

Cirrhosis/Liver failure?

Blindness?

Liver cancer?

Heart attack?

Death?

$11 \% \quad 31 \% \quad 57 \%$

$81 \% \quad 3 \% \quad 16 \%$

$38 \% \quad 15 \% \quad 47 \%$

$62 \% \quad 9 \% \quad 27 \%$

$18 \% \quad 33 \% \quad 49 \%$

$79 \% \quad 3 \% \quad 18 \%$

What makes HCV worse for the people that have it?**

Drinking coffee?

Drinking alcohol?

HIV infection?

Being obese?

Does everyone who has HCV need treatment?**

$4 \% \quad 56 \% \quad 41 \%$

$82 \% \quad 6 \% \quad 11 \%$

$82 \% \quad 3 \% \quad 15 \%$

$\quad 34 \% \quad 26 \% \quad 41 \%$

$\quad 76 \% \quad 10 \% \quad 14 \%$

How many people who get treated for HCV, get cured?**

All

$3 \%$

Some

$33 \%$

None

$29 \%$

Not sure

$36 \%$

Do you think that the side effects of HCV treatment are very bad?

Yes

$21 \%$

Somewhat

$17 \%$

No

$14 \%$

Not Sure

$49 \%$

Would you get a free blood test for HCV?

Would you want to get treated for HCV if you tested positive?

Would you want to be tested for HCV, if when you tested positive you could get free treatment?

$97 \% \quad 2 \% \quad 1 \%$

$98 \% \quad 1 \% \quad 1 \%$

$99 \% \quad 0 \% \quad 1 \%$

$\begin{array}{lll}90 \% & 10 \% \quad 0 \%\end{array}$

$95 \% \quad 5 \% \quad 0 \%$ 


\section{Table 2 Proportions and frequencies of pre-test survey answers (Continued)}

Would you still want to be tested if you were told you could not be offered treatment, but you could get lifestyle

advice on how to stay healthy with HCV?

Do you want free HCV testing in your community?

Do you think other people would want free HCV testing?

If people in the community tested positive for HCV, do you think they would do the following things if they were told it would help them?

Drink less alcohol?

Get a shot against HAV/HBV?

Go to the doctor for treatment?

Do you think it will be a problem if we tested for HCV in your community but might not be able to offer treatment to everyone who's positive?

*Among persons not reporting HCV infection

${ }^{* *}$ Questions that were used in composite knowledge score.

Table 3 Analysis of Pre and posttest changes of answers

\begin{tabular}{|c|c|c|c|}
\hline Knowledge related questions & $\begin{array}{l}\text { Pre-test } \\
\text { \% correct }\end{array}$ & $\begin{array}{l}\text { Post-test } \\
\% \text { correct }\end{array}$ & $\begin{array}{l}\text { p-value } \\
\text { (McNemar) }\end{array}$ \\
\hline \multicolumn{4}{|l|}{ How do you think people get HCV? } \\
\hline Having sex? & $56 \%$ & $84 \%$ & $<0.0001$ \\
\hline Shooting up (injecting) drugs? & $90 \%$ & $98 \%$ & 0.001 \\
\hline Using public toilets? & $60 \%$ & $95 \%$ & $<0.0001$ \\
\hline Sharing supplies for snorting drugs? & $54 \%$ & $85 \%$ & $<0.0001$ \\
\hline Coughing/sneezing on someone? & $52 \%$ & $94 \%$ & $<0.0001$ \\
\hline Getting a homemade tattoo? & $89 \%$ & $97 \%$ & 0.0074 \\
\hline \multicolumn{4}{|l|}{ What makes HCV worse for the people who have it? } \\
\hline Drinking coffee? & $45 \%$ & $86 \%$ & $<0.0001$ \\
\hline Drinking alcohol? & $82 \%$ & $96 \%$ & $<0.0001$ \\
\hline HIV infection? & $82 \%$ & $89 \%$ & 0.121 \\
\hline Being obese? & $33 \%$ & $80 \%$ & $<0.0001$ \\
\hline Does everyone who has HCV need treatment? & $10 \%$ & $81 \%$ & $<0.0001$ \\
\hline How many people who get treated for HCV get cured? & $33 \%$ & $90 \%$ & $<0.0001$ \\
\hline Attitude related questions & $\begin{array}{l}\text { Pre-test } \% \\
\text { answered yes }\end{array}$ & $\begin{array}{l}\text { Post-test \% } \\
\text { answered yes }\end{array}$ & $\begin{array}{l}\text { p-value } \\
\text { (McNemar) }\end{array}$ \\
\hline $\begin{array}{l}\text { Would you want to be tested for HCV, if when you tested positive you could get free } \\
\text { treatment? }\end{array}$ & $99 \%$ & $100 \%$ & 1.0 \\
\hline Would you still want to be tested, if you were told you could not be offered treatment? & $90 \%$ & $90 \%$ & 1.0 \\
\hline $\begin{array}{l}\text { Would you still want to be tested if you were told you could not be offered treatment, but you } \\
\text { could get free vaccines against HAV/HBV? }\end{array}$ & $95 \%$ & $96 \%$ & .727 \\
\hline $\begin{array}{l}\text { Would you still want to be tested if you were told you could not be offered treatment, but you } \\
\text { could get lifestyle advice on how to stay healthy with HCV? }\end{array}$ & $96 \%$ & $95 \%$ & 1.0 \\
\hline Do you want free HCV testing in your community? & $99 \%$ & $97 \%$ & 0.25 \\
\hline Do you think other people would want free HCV testing? & $86 \%$ & $92 \%$ & 0.077 \\
\hline $\begin{array}{l}\text { Do you think it will be a problem if we tested for HCV in your community but might not be } \\
\text { able to offer treatment to everyone who's positive? }\end{array}$ & $49 \%$ & $35 \%$ & 0.019 \\
\hline \multicolumn{4}{|l|}{$\begin{array}{l}\text { If people tested positive for HCV, do you think people would do the following if they were told } \\
\text { it would help them? }\end{array}$} \\
\hline Drink less alcohol? & $39 \%$ & $54 \%$ & 0.003 \\
\hline Get a shot against HAV/HBV? & $83 \%$ & $86 \%$ & .383 \\
\hline Go to the doctor for treatment? & $76 \%$ & $79 \%$ & .524 \\
\hline
\end{tabular}


percent of participants understood that treatment was not compulsory for everyone with $\mathrm{HCV}$, as compared to $10 \%$ pre-education $(\mathrm{p}<0.0001)$. Ninety percent $(90 \%)$ of participants gave correct responses regarding $\mathrm{HCV}$ cure rates after the educational intervention, as opposed to $33 \%$ pre-education $(\mathrm{p}<0.0001)$. After learning about the deleterious effects of alcohol in patients with HCV, significantly more participants believed that people in the community who tested positive for $\mathrm{HCV}$ would drink less alcohol $(p=0.003)$. Attitudes toward personal acceptance of $\mathrm{HCV}$ testing did not change after education since almost all participants wanted to be tested on the pre-intervention survey. However, the participants' perceived acceptability of HCV screening among other members of the community did increase after education. Importantly, after education, participants were significantly less likely to believe that offering community-based HCV screening without guarantee of universal treatment would be problematic (49\% pre-intervention believed this would be problematic vs. $35 \%$ post-education, $\mathrm{p}=0.02$ ).

\section{Knowledge score and associations}

The mean baseline knowledge score was 9.9 (SD 3.3), ranging from 0-18. Characteristics associated with greater knowledge were male gender, white race, younger age, and knowing someone with HCV (Table 4). Interestingly, participants who did not want to be tested for HCV if they were not guaranteed treatment had significantly lower knowledge scores than people who wanted to know their HCV status despite availability of treatment $(p=0.003)$. When dichotomizing age based on the CDC screening recommendations, participants greater than 45 years old (baby boomer generation) had mean knowledge scores that were lower than younger participants, though this did not reach statistical significance (9.5 vs. $10.4, \mathrm{p}=0.08)$. In multivariable analysis, white race, male gender, knowing a person with $\mathrm{HCV}$, and wanting $\mathrm{HCV}$ testing even if treatment could not be offered remained associated with higher knowledge scores (Table 5).

\section{Discussion}

In an attempt to curtail the rising morbidity and mortality from undiagnosed $\mathrm{HCV}$, the CDC and USPSTF have expanded screening guidelines to high-risk individuals and persons born 1945-1965 [9-11]. Community-based screening programs have the potential to reach such persons [12,13]; however, it is important to understand the acceptability of $\mathrm{HCV}$ testing in a group that may have limited access to HCV medical treatment. In this study, we found that people who access community-based, non-traditional testing sites were highly accepting of $\mathrm{HCV}$ screening, even without guarantee of treatment. On the other hand, high-risk individuals lacked knowledge about
Table 4 Bivariate analysis of knowledge score

\begin{tabular}{|c|c|c|}
\hline Variable $(n)$ & $\begin{array}{l}\text { Mean (SD) } \\
\text { knowledge score } \\
\text { or correlation } \\
\text { coefficient }\end{array}$ & $\mathrm{p}$-value \\
\hline Total & $9.9(3.3)$ & \\
\hline Age (140) & $r=-0.17$ & 0.04 \\
\hline \multicolumn{3}{|l|}{ Gender } \\
\hline Male (92) & $10.4(.35)$ & 0.02 \\
\hline Female (48) & $9.1(.44)$ & \\
\hline \multicolumn{3}{|l|}{ Race } \\
\hline White (52) & $10.8(2.8)$ & \\
\hline Non-white (88) & $9.4(3.5)$ & 0.02 \\
\hline \multicolumn{3}{|l|}{ Regular doctor } \\
\hline Yes (68) & $9.8(3.0)$ & 0.64 \\
\hline No (72) & $10.1(3.6)$ & \\
\hline \multicolumn{3}{|l|}{ Education } \\
\hline Elementary (22) & $9.4(3.6)$ & \\
\hline High school (55) & $9.5(3.4)$ & 0.11 \\
\hline Some college & $10.1(3.0)$ & \\
\hline Finished college & $11.5(2.9)$ & \\
\hline \multicolumn{3}{|l|}{ Insurance } \\
\hline Yes (102) & $10.0(3.5)$ & 0.83 \\
\hline No (38) & $9.8(2.7)$ & \\
\hline \multicolumn{3}{|c|}{ Do you know anyone with HCV? } \\
\hline Yes (79) & $10.5(3.1)$ & 0.03 \\
\hline No (55) & $9.3(3.5)$ & \\
\hline \multicolumn{3}{|l|}{ Do you have HCV? } \\
\hline Yes (25) & $10.6(3.8)$ & 0.24 \\
\hline No (112) & $9.8(3.2)$ & \\
\hline \multicolumn{3}{|c|}{$\begin{array}{l}\text { Would you still want to be tested } \\
\text { if you could not get treatment? }\end{array}$} \\
\hline Yes (126) & $10.2(3.1)$ & 0.003 \\
\hline No (14) & $7.5(3.7)$ & \\
\hline
\end{tabular}

$\mathrm{HCV}$. Nonetheless, an easy on-site educational intervention significantly improved HCV knowledge and also increased acceptability of testing.

To our knowledge, this is the first study to directly assess acceptability rates of HCV screening when access issues were explicitly stated. We found that acceptability of screening was almost universal in this population, and remained high even when participants were told that they would not be able to receive treatment. Ninety seven percent of participants said that they would personally obtain a free $\mathrm{HCV}$ test, and 99\% stated they would want free HCV testing in their community. Even when told they would not be able to receive treatment, $90 \%$ of participants said they would still want to know their HCV status. When told that free hepatitis A/B 


\begin{tabular}{|c|c|c|c|}
\hline Characteristics* & $\begin{array}{l}\text { Adjusted } \\
\text { mean }\end{array}$ & p-value & $\begin{array}{l}\text { Beta } \\
\text { coefficient } \\
\text { (s.e.) }\end{array}$ \\
\hline \multicolumn{4}{|l|}{ Age } \\
\hline 31 years ( -1 SD below mean) & 10.37 & 0.271 & $-.026(.024)$ \\
\hline 56 years (+1SD above mean) & 9.72 & & \\
\hline \multicolumn{4}{|l|}{ Gender } \\
\hline Male & 10.60 & 0.002 & $-1.76(.566)$ \\
\hline Female & 8.84 & & \\
\hline \multicolumn{4}{|l|}{ Race } \\
\hline White & 10.70 & 0.065 & $-1.13(.605)$ \\
\hline Non-white & 9.57 & & \\
\hline \multicolumn{4}{|l|}{$\begin{array}{l}\text { Do you know someone with } \\
\text { HCV? }\end{array}$} \\
\hline No & 9.28 & 0.025 & $1.22(.540)$ \\
\hline Yes & 10.50 & & \\
\hline \multicolumn{4}{|l|}{$\begin{array}{l}\text { Would want to be tested even } \\
\text { if can't be offered treatment? }\end{array}$} \\
\hline No & 7.71 & 0.005 & $2.53(.890)$ \\
\hline Yes & 10.25 & & \\
\hline
\end{tabular}

*Referent group placed first under each category.

vaccination or advice on harm reduction could be offered, almost all participants again wanted to be tested regardless of availability of medical therapy. These data demonstrate how strongly people at-risk for $\mathrm{HCV}$ value knowing their status.

This is important because testing persons for HCV, even without access to medication, can still be beneficial. Public health departments are in a unique position to address lack of screening and care to populations that are specifically at risk for $\mathrm{HCV}$, such as the homeless, people who inject drugs (PWID), and uninsured babyboomers [14-16]. Early HCV detection provides an opportunity for low-cost interventions that can decrease the risk of liver disease including alcohol reduction counseling, HIV testing, and immunization against hepatitis A and B that are often available through public health services [17-19]. Furthermore, knowledge of one's disease allows opportunity to seek out health insurance (something that may become easier under the Affordable Care Act), resulting in access to therapies at an earlier stage of liver disease, which is associated with better treatment response rates and less risk of long term liver complications [20-22]. As newer medical therapies with improved efficacy and side effect profiles become increasingly available, early identification of disease by $\mathrm{HCV}$ screening will have greater potential to reduce poor outcomes [23-25].
Importantly, other community based organizations, such as opioid treatment centers and urban primary care clinics, have been shown to increase $\mathrm{HCV}$ testing rates in high prevalence populations [26-28]. These communitybased settings are unique in that, not only are they able to establish HCV positivity through screening programs, they are often able to offer HCV care and medical therapy, taking advantage of an already engaged at-risk population. Through a multidisciplinary treatment model-with onsite drug, psychiatric, and medical care- $\mathrm{HCV}$ treatment was shown to be effective in a large population of opioid dependent patients in a methadone maintenance program in the Bronx, NY [29]. Community-based screening can therefore act as the initial step to improving the entire cascade of $\mathrm{HCV}$ care for hard-to-reach populations.

Though acceptance of HCV screening in our high-risk population was high, knowledge regarding $\mathrm{HCV}$ was relatively poor. This lack of knowledge was surprising given over half of participants reported knowing someone with $\mathrm{HCV}$ and $18 \%$ of participants stated that they personally were infected with HCV. Our work supports prior investigations that have shown significant gaps in HCV knowledge in high-risk groups, such as persons living with HIV and intravenous drug users [30-33]. Similar to these studies, we found that lack of knowledge was associated with African American race, a group that is disproportionately afflicted by this disease. Participants demonstrated poor knowledge about $\mathrm{HCV}$ acquisition, which may impact a person's ability to make choices that protect themselves and prevent transmission to others in their community. As shown previously [34], we also found a large percentage of people who did not know that alcohol or HIV could worsen HCV disease progression, and even fewer knew that obesity has a negative effect on liver health. This dearth of information makes it difficult for HCV positive people to make healthy lifestyle choices when living with $\mathrm{HCV}$. There were also significant misconceptions in understanding HCV therapy, as most people believed that it was necessary to treat all HCV positive persons. A majority of participants were also unsure or did not think that HCV could be cured and over half carried erroneous beliefs regarding $\mathrm{HCV}$ treatment side effects. This supports previous work by Krauskopf et al., where only $25 \%$ of an inner-city community believed there to be a cure for $\mathrm{HCV}$ [33]. This hinders the ability of $\mathrm{HCV}$ positive persons to appropriately interpret their disease and lessens their interest in care, potentially contributing to the persistently low uptake of HCV treatment $[35,36]$.

Fortunately, a brief educational intervention significantly improved HCV knowledge among the participants. Almost all areas of HCV knowledge improved post-intervention, with the greatest changes occurring in understanding of treatment. Notably, improvement in 
HCV knowledge has been shown to improve compliance with linkage to HCV care [35,36].

By increasing knowledge, our educational tool also increased acceptance rates for HCV testing. Although personal acceptance of testing was high at baseline, some participants expressed concern regarding the community's desire for screening if access to treatment was not universal. That said, those who were concerned about community acceptance demonstrated significantly more positive attitudes toward HCV screening after education was provided. Furthermore, the small minority of individuals hesitant to be personally tested without a guarantee of treatment demonstrated lower HCV knowledge scores, even when adjusted for other variables. This is consistent with other studies that show improved knowledge leads to greater interest in HCV care [36-38]. These findings underscore the importance of continued community education to enhance both knowledge of $\mathrm{HCV}$ and acceptance of HCV screening and care.

This study has several limitations. Our population consisted of a convenience sample of high-risk individuals that access non-traditional testing sites of an urban health department in the southern United States. Though this is a highly specific community, these participants did indeed have traditional risk factors for $\mathrm{HCV}$ that one would expect in other at-risk populations, such as drug use, homelessness, and African American race. Because many of the participants were in drug/alcohol rehabilitation programs, they may have been more motivated to provide positive responses to survey questions than others in their communities. Verbal administration of the surveys may have also biased the participants to provide more positive responses than a written instrument. Therefore, our results regarding acceptance may not be generalizable to the entire at-risk population. Also, we assessed the impact of the educational intervention immediately following the discussion, so we cannot comment as to whether the improvement in knowledge was durable, though other studies of brief educational interventions have shown sustainability of knowledge from 1 to 18 months later [39,40]. Finally, since a member of the study team verbally administered the education intervention, its reproducibility cannot be guaranteed.

\section{Conclusions}

Acceptance of community-based HCV screening amongst a high-risk population was almost universal, even without guarantee of treatment. Despite inconsistencies in availability of $\mathrm{HCV}$ medications and poor knowledge regarding $\mathrm{HCV}$, high-risk communities are ready to know their HCV status. Furthermore, a screening strategy that implements brief on-site education can aid in improving $\mathrm{HCV}$ knowledge and engagement in care and testing. These data support the establishment of programs that utilize community-based screening, and also provide initial evidence for acceptance of the implementation of the recently expanded screening guidelines among marginalized communities.

\section{Competing interests}

The authors declare that they have no competing interests.

\section{Authors' contributions}

BN took part in the conception, design, acquisition of data, data analysis, and was the primary person in drafting the manuscript. CV took part in the conception, design, analysis and interpretation of data, as well as revising the manuscript. ST took part in the acquisition of data, analysis of data and revising manuscript. EH took part in the design of the project, acquisition of data, and revision of manuscript. NG took part in the design of the project, acquisition of data, and revision of manuscript. KH took part in the acquisition of data, analysis and interpretation of data, and revision of manuscript. AL took part in the acquisition of data, and revision of manuscript. SN took part in the conception and design of project, interpretation of data, and revision of manuscript. JS took part in the conception and design of the project, acquisition of data, data analysis, and revision of the manuscript. All authors read and approved the final manuscript.

\section{Acknowledgment}

This work was supported in part by the Department of Veterans Affairs, Veterans Health Administration, Office of Research and Development, AHRQ Fellowship [\#T32 HS00079-01-31 (to BLN)]

\section{Author details}

'Division of Infectious Diseases and International Health, Duke University Medical Center, Box 102358, Durham, NC 27710, USA. ²Durham VA Medical Center and Division of General Internal Medicine, Duke University Medical Center, Durham, NC, USA. ${ }^{3}$ School of Nursing, Duke University Medical Center, Durham, NC, USA. ${ }^{4}$ Division of Rheumatology and Immunology, Duke University Medical Center, Durham, NC, USA.

Received: 28 August 2013 Accepted: 28 January 2014 Published: 10 February 2014

\section{References}

1. Armstrong GL, Wasley A, Simard EP, McQuillan GM, Kuhnert WL, Alter MJ: The prevalence of hepatitis C virus infection in the United States, 1999 through 2002. Ann Intern Med 2006, 144(10):705-714.

2. US Department of Health and Human Services: Combating the Silent Epidemic of Viral Hepatitis (Action Plan for the Prevention, Care, and Treatment of Viral Hepatitis). 2011

3. Verna EC, Brown RS Jr: Hepatitis C virus and liver transplantation. Clin Liver Dis 2006, 10(4):919-940.

4. Mitchell AE, Colvin HM, Palmer Beasley R: Institute of Medicine recommendations for the prevention and control of hepatitis $B$ and $C$. Hepatology 2010, 51(3):729-733.

5. Hagan H, Campbell J, Thiede H, Strathdee S, Ouellet L, Kapadia F, Hudson S, Garfein RS: Self-reported hepatitis C virus antibody status and risk behavior in young injectors. Public Health Rep 2006, 121(6):710-719.

6. Ly KN, Xing J, Klevens RM, Jiles RB, Ward JW, Holmberg SD: The increasing burden of mortality from viral hepatitis in the United States between 1999 and 2007. Ann Intern Med 2012, 156(4):271-278.

7. Davis GL, Alter MJ, El-Serag H, Poynard T, Jennings LW: Aging of hepatitis C virus (HCV)-infected persons in the United States: a multiple cohort model of HCV prevalence and disease progression. Gastroenterology 2010, 138(2):513-521. 521 e511-516.

8. Rein DB, Wittenborn JS, Weinbaum CM, Sabin M, Smith BD, Lesesne SB: Forecasting the morbidity and mortality associated with prevalent cases of pre-cirrhotic chronic hepatitis C in the United States. Dig Liver Dis 2011, 43(1):66-72.

9. Centers for Disease Control and Prevention: Recommendations for prevention and control of hepatitis C virus (HCV) infection and HCVrelated chronic disease. MMWR Recomm Rep 1998, 47(RR-19):1-39. 
10. Smith BD, Morgan RL, Beckett GA, Falck-Ytter Y, Holtzman D, Ward JW: Hepatitis C virus testing of persons born during 1945-1965: recommendations from the Centers for Disease Control and Prevention. Ann Intern Med 2012, 157(11):817-822.

11. Moyer VA: Screening for Hepatitis C Virus Infection in Adults: U.S. Preventive Services Task Force Recommendation Statement. Ann Intern Med 2013.

12. Guerrero HJ GW, Fullmer C: A Novel Method of Reaching at-Risk Populations in Community Outreach Hepatitis Screening Programs. San Fransisco, CA: AASLD; 2008.

13. Subiadur J, Harris $\lrcorner$, Rietmeijer CA: Integrating viral hepatitis prevention services into an urban STD clinic: Denver, Colorado. Public Health Rep 2007, 122(Suppl 2):12-17.

14. Gunn RA, Murray PJ, Ackers ML, Hardison WG, Margolis HS: Screening for chronic hepatitis $B$ and $C$ virus infections in an urban sexually transmitted disease clinic: rationale for integrating services. Sex Transm Dis 2001, 28(3):166-170.

15. Hadley J, Cunningham P: Availability of safety net providers and access to care of uninsured persons. Health Serv Res 2004, 39(5):1527-1546.

16. Gunn RA, Murray PJ, Brennan CH, Callahan DB, Alter MJ, Margolis HS: Evaluation of screening criteria to identify persons with hepatitis $C$ virus infection among sexually transmitted disease clinic clients: results from the San Diego Viral Hepatitis Integration Project. Sex Transm Dis 2003, 30(4):340-344

17. McCusker M: Influence of hepatitis $\mathrm{C}$ status on alcohol consumption in opiate users in treatment. Addiction 2001, 96(7):1007-1014.

18. Dieperink E, Ho SB, Heit S, Durfee JM, Thuras P, Willenbring ML: Significant reductions in drinking following brief alcohol treatment provided in a hepatitis C clinic. Psychosomatics 2010, 51(2):149-156.

19. Ghany MG, Strader DB, Thomas DL, Seeff LB: Diagnosis, management, and treatment of hepatitis C: an update. Hepatology 2009, 49(4):1335-1374.

20. Zeuzem S: Heterogeneous virologic response rates to interferon-based therapy in patients with chronic hepatitis C: who responds less well? Ann Intern Med 2004, 140(5):370-381.

21. Davis GL, Lau JY: Factors predictive of a beneficial response to therapy of hepatitis C. Hepatology 1997, 26(3 Suppl 1):122S-127S.

22. Cheng WS, Roberts SK, McCaughan G, Sievert W, Weltman M, Crawford D, Rawlinson W, Marks PS, Thommes J, Rizkalla B, et al: Low virological response and high relapse rates in hepatitis $C$ genotype 1 patients with advanced fibrosis despite adequate therapeutic dosing. J Hepatol 2010, 53(4):616-623.

23. Jacobson IM, Gordon SC, Kowdley KV, Yoshida EM, Rodriguez-Torres M, Sulkowski MS, Shiffman ML, Lawitz E, Everson G, Bennett M, et al: Sofosbuvir for hepatitis $C$ genotype 2 or 3 in patients without treatment options. N Engl J Med 2013, 368(20):1867-1877.

24. Lawitz E, Mangia A, Wyles D, Rodriguez-Torres M, Hassanein T, Gordon SC, Schultz M, Davis MN, Kayali Z, Reddy KR, et al: Sofosbuvir for previously untreated chronic hepatitis C infection. N Engl J Med 2013, 368(20):1878-1887

25. Hunt $D$, Pockros $P$ : What are the promising new therapies in the field of chronic hepatitis $C$ after the first-generation direct-acting antivirals? Curr Gastroenterol Rep 2013, 15(1):303.

26. Litwin $\mathrm{AH}$, Soloway I, Gourevitch MN: Integrating services for injection drug users infected with hepatitis $C$ virus with methadone maintenance treatment: challenges and opportunities. Clin Infect Dis 2005, 40(Suppl 5):S339-345.

27. Litwin AH, Smith BD, Drainoni ML, McKee D, Gifford AL, Koppelman E, Christiansen CL, Weinbaum CM, Southern WN: Primary care-based interventions are associated with increases in hepatitis $C$ virus testing for patients at risk. Dig Liver Dis 2012, 44(6):497-503.

28. Drainoni ML, Litwin AH, Smith BD, Koppelman EA, McKee MD, Christiansen $C L$, Gifford AL, Weinbaum CM, Southern WN: Effectiveness of a risk screener in identifying hepatitis $C$ virus in a primary care setting. Am J Public Health 2012, 102(11):e115-121.

29. Litwin AH, Harris KA Jr, Nahvi S, Zamor PJ, Soloway IJ, Tenore PL, Kaswan D, Gourevitch MN, Arnsten JH: Successful treatment of chronic hepatitis C with pegylated interferon in combination with ribavirin in a methadone maintenance treatment program. J Subst Abuse Treat 2009, 37(1):32-40.

30. Proeschold-Bell RJ, Hoeppner B, Taylor B, Cohen S, Blouin R, Stringfield B, Muir AJ: An interrupted time series evaluation of a hepatitis $C$ intervention for persons with HIV. AIDS Behav 2011, 15(8):1721-1731.
31. O'Brien S, Day C, Black E, Dolan K: Injecting drug users' understanding of hepatitis C. Addict Behav 2008, 33(12):1602-1605.

32. Proeschold-Bell RJ, Blouin R, Reif S, Amana A, Rowland BJ, Lombard F, Stringfield B, Muir AJ: Hepatitis C transmission, prevention, and treatment knowledge among patients with HIV. South Med J 2010, 103(7):635-641.

33. Krauskopf K, McGinn TG, Federman AD, Halm EA, Leventhal H, McGinn LK, Gardenier D, Oster A, Kronish IM: HIV and HCV health beliefs in an inner-city community. J Viral Hepat 2011, 18(11):785-791.

34. Treloar C, Hull P, Dore GJ, Grebely J: Knowledge and barriers associated with assessment and treatment for hepatitis $C$ virus infection among people who inject drugs. Drug Alcohol Rev 2012, 31(7):918-924.

35. Mehta SH, Genberg BL, Astemborski J, Kavasery R, Kirk GD, Vlahov D, Strathdee SA, Thomas DL: Limited uptake of hepatitis $C$ treatment among injection drug users. J Community Health 2008, 33(3):126-133.

36. Surjadi M, Torruellas C, Ayala C, Yee HF Jr, Khalili M: Formal patient education improves patient knowledge of hepatitis $C$ in vulnerable populations. Dig Dis Sci 2011, 56(1):213-219.

37. Doab A, Treloar C, Dore GJ: Knowledge and attitudes about treatment for hepatitis $C$ virus infection and barriers to treatment among current injection drug users in Australia. Clin Infect Dis 2005, 40(Suppl 5):S313-320.

38. Lubega S, Agbim U, Surjadi M, Mahoney M, Khalili M: Formal hepatitis C education enhances HCV care coordination, expedites HCV treatment and improves antiviral response. Liver Int 2013, 33(7):999-1007.

39. Hawthorne K, Robles Y, Cannings-John R, Edwards AG: Culturally appropriate health education for type 2 diabetes mellitus in ethnic minority groups. Cochrane Database Syst Rev 2008, 3:CD006424.

40. Kiene SM, Barta WD: A brief individualized computer-delivered sexual risk reduction intervention increases HIV/AIDS preventive behavior. J Adolesc Health 2006, 39(3):404-410.

doi:10.1186/1471-2334-14-74

Cite this article as: Norton et al:: Community-based HCV screening:

knowledge and attitudes in a high risk urban population. BMC Infectious Diseases 2014 14:74.

\section{Submit your next manuscript to BioMed Central and take full advantage of:}

- Convenient online submission

- Thorough peer review

- No space constraints or color figure charges

- Immediate publication on acceptance

- Inclusion in PubMed, CAS, Scopus and Google Scholar

- Research which is freely available for redistribution

Submit your manuscript at www.biomedcentral.com/submit
C) Biomed Central 